\title{
YOU-WILL-KILL-ME BEANS: Taste and the Politics of Necessity in Humanitarian Aid
}

\author{
MICAH M. TRAPP \\ University of Memphis \\ (D) http: / / orcid.org/0000-0002-0741-4586
}

Praise Restaurant and Fast Food, your satisfaction is our concern

Rice and soup

Dried rice and fried fis

Fufu and soup

Tea_-Oats-Soft drinks

Spaghetti, Malta \& Cow meat

- Cook shop menu board at the Buduburam Liberian refugee camp

The sumptuous pleasure of kiss meat comes from sucking the juices through its briny shell. Although they require a massive amount of labor to harvest, clean, and prepare, the small river snails that Liberians call kiss meat taste sublime and are touted as being able to enhance one's kissing skills. Although the tiny gray snail can be prepared in many ways, including barbecued with peanuts and hot pepper, kiss meat stewed in the buttery red fruit of the palm tree is particularly rich. An American journalist encountering Liberians eating river snails during the civil wars that wracked the country between 1989 and 2003 called these creatures "iron meat"; her designation was intended to highlight the resilience of Liberians devastated by war, and to position those who were willing to scavenge for such small, difficul forms of protein and sustenance as worthy subjects of aid in the humanitarian landscape that the hostilities had created. However, the harsh con- 
ditions of the wars, captured in the new moniker iron meat, removed the river snails from their sensual aesthetic as kiss meat and marked them as an undignified rote, and compulsory form of subsistence. Kiss meat was no longer desirable; it was, as iron meat, merely edible.

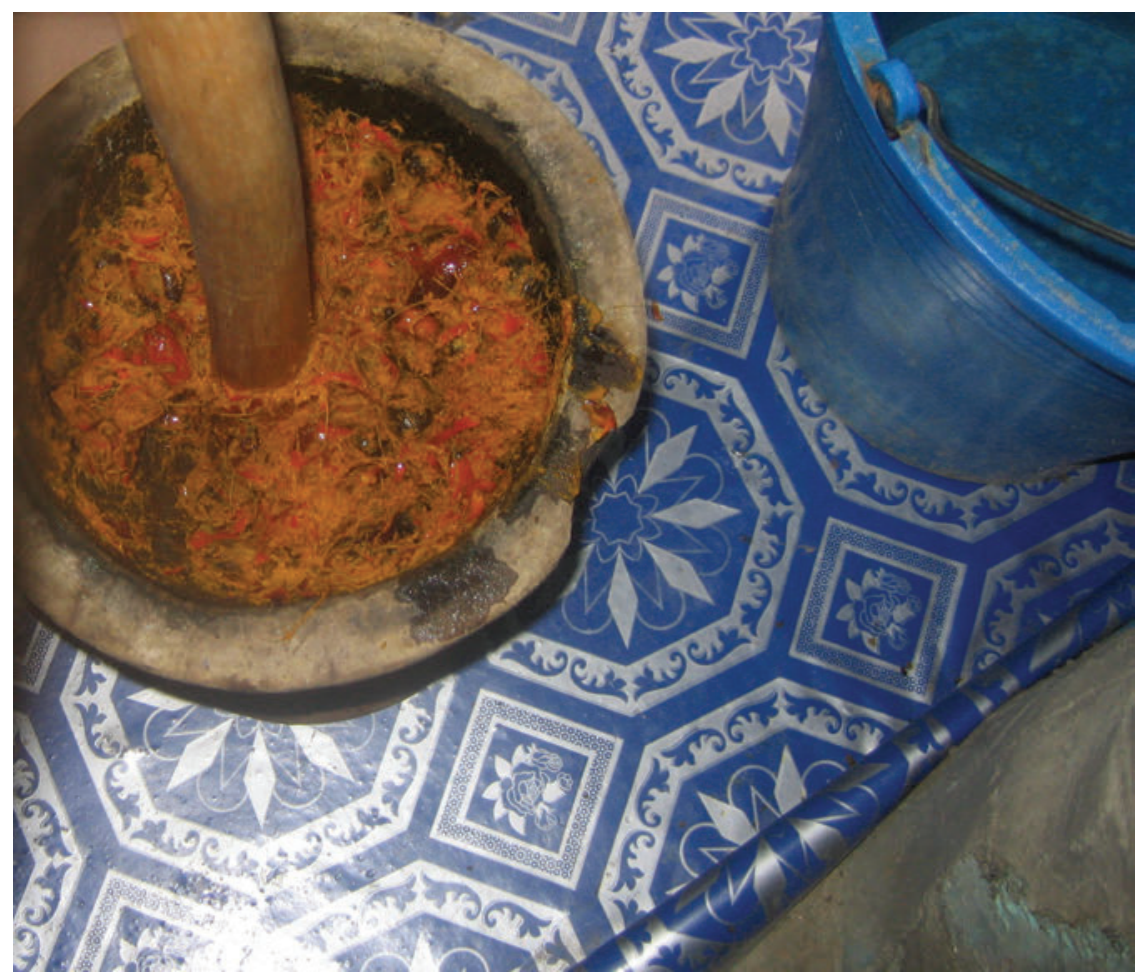

Figure 1. Preparing palm butter. Photo by Micah Trapp.

The primary objective of many humanitarian projects is to save lives that have been deemed worthy of salvation (Fassin 2012; Fassin and Rechtman 2009; Redfiel and Bornstein 2010). ${ }^{1}$ Sensory pleasure, or a focus on the taste of food provisions, often remains obscured by conditions of scarcity, the caloric demands of aid, and the imperative to provide adequate nutrition and sustain precarious lives. In the biopolitical domain of the refugee camp, food is a site of gustatory discipline. In 2002, for example, the Zambian president Levy Mwanawasa was accused of allowing his people starve when he refused to accept genetically modifie food aid from the United States. Mwanawasa's decision marks a demonstrable critique of the politics of necessity (Annear 2004). But many humanitarian subjects — including refugees — do not often have such political powers. In my work 
in the Buduburam Liberian refugee camp, located forty kilometers west of Accra, Ghana, I have sought to understand how refugees' demand for food with what they consider to be good taste is configure in equations of who is deserving, or in need of, humanitarian aid. My questions have centered on how the politics of necessity shape food provision as humanitarian aid. Central to these inquiries are the critical opportunities afforded to refugee subjects by the aesthetics of tastehow cooking and taste reveal forms of refugee subjectivities that counter the humanitarian politics of necessity.

The dominant humanitarian logic that seems to demand tasteless subjects reflect the broader narrative of loss surrounding notions of modern food supply in sub-Saharan Africa (Freidberg 2003). But at Buduburam, Liberians did not simply reject or assimilate to the tastes of aid. Rather, taste was a fundamental component in the humanitarian struggle. Building on ten months of research in the camp between 2005 and 2008-2009, I argue in this article that Liberian refugees have challenged the humanitarian politics of necessity by producing biographies of food aid and a public accounting of the historic and contemporary conditions of humanitarianism. By prioritizing the taste of refugee food, camp residents have challenged the reason of humanitarian reason by expanding the sensibility of food aid and repositioning recipients as essential figure in humanitarian aid.

\section{A TASTE FOR SUFFERING}

Taste occupies a contentious place in humanitarian food aid. As guests at the humanitarian table, refugees are expected and assumed to adapt to the most economical foods, those that provide the most caloric content and nutritional components at the lowest possible price. The "tastes of necessity," as Pierre Bourdieu $(1984,168)$ put it, become a politics of necessity that pivots between economic and humanitarian logics regarding what the qualities of food aid should be and to whom it should go. Anthropologists have understood that food practices shift to accommodate and incorporate new, less desirable foods during periods of war and migration (Macbeth 1997; Mintz 1996). However, analyses of specifi cooking techniques have demonstrated that managing and manipulating foods is not simply a matter of assimilating to new cuisines or products, but can be in themselves acts of contestation and critique (Wilk 2006, 109). Elizabeth Dunn (2011, 140-41) found, for example, that Georgian refugees rejected food aid such as macaroni, claiming they were "foods of sorrow" and "anti-artifacts." These provisions were not capable of sustaining social connections, meanings, and prac- 
tices. Foods of sorrow reflecte the propensity of humanitarian aid to produce nothing of social value, to foster passivity, and to entrench a form of taste-less misery.

Physical and psychological suffering, as moral and bodily conditions, often function as the central justificatio for humanitarian intervention, and refugees are expected to produce grateful, embodied performances of the "mute victim" (Redfiel and Bornstein 2010, 17-18; see also Malkki 1996; Ticktin 2011, 13). In Casualties of Care, Miriam Ticktin (2011) outlines the antipolitics of care that lies at the core of humanitarian aid to demonstrate how the moral dimensions of compassion and care carried out by humanitarian aid workers remain linked to the oppressive measures that prevent others from receiving aid, often on the basis of normative morality. For Ticktin $(2011,5)$, "armed love" reflect how the protection of and care for suffering subjects are accompanied by and mask the violence toward and containment of those who have failed to meet the standards expected of a worthy recipient. What Ticktin rightly find is that the human universals reproduced by the moral pursuit of compassion reenact gender and racial inequalities.

In Humanitarian Reason, Didier Fassin $(2012,226)$ looks beyond humanitarianism's biopolitical technologies of management and care and focuses on the "politics of life" that "bring into play differentiated meanings and values of human lives." With a politics of life, Fassin refers to the public manifestations and negotiations of humanitarianism's moral logic, which he locates in the concept of humanitarian reason. Humanitarian reason may aim to save lives, but it must also determine which lives are worthy of salvation. Premised on a Christian theology that places biological life at the apex of value - what Fassin $(2012,249)$ calls "biolegitimacy" - humanitarian reason asserts a single moral economy in which all human life is rendered equal. In practice, moral concern for human suffering fuses with the politics of governing the lives of precarious subjects. The principled language of humanitarian reason has shifted from a vocabulary of social critique to a supposedly self-evident application based on moral sentiment and compassion: injustice reappears as suffering, violence manifests as trauma, and domination becomes a matter of misfortune (Fassin 2012, 6-7, 247). Socially structured inequality between humanitarian benefactors and humanitarian recipients ensures the reproduction of inequalities; the altruistic impulses of the giver have precedence over the rights of the receiver (Fassin 2012, 253). Humanitarianism compels its subjects to mimic the tropes of suffering and redemption to reproduce 
its reason (Agier 2010; Fassin 2012; Feldman 2012; Knudsen 1995; McKay 2012; Ticktin 2011).

In response to the ever-suffering victim created by humanitarianism, Miriam Ticktin (2014, 283-84) has called for a conceptual shift away from focusing all attentions on abject misery. But as a field the study of transnational humanitarianism has clear applied implications for the practice of humanitarian aid. To evacuate suffering is to challenge an ever-present and sensitive point: the humanitarian apparatus requires suffering, and refusing to focus on need in the refugee camp can imply its lack of care and therefore undercut the reason and pursuit of humanitarian intervention. ${ }^{2}$ At the Buduburam camp, where the emergency phase of humanitarian aid had ended and residents remained plagued by chronic inequalities and poverty, I decentered the suffering body, as well as the Enlightenment preference for voice, vision, and reason. ${ }^{3}$ My intervention is not about individual action or resistance to the humanitarian apparatus; rather, my work takes issue with the reason of humanitarian reason and shifts the focus from suffering to tasting subjects, ones who do not simply mimic and take on the language of humanitarianism but collectively engage and critique its reason.

In his well-known introduction to The Taste of Ethnographic Things, Paul Stoller $(1989$, 19-21) tells the story of Djebo, a young Songhay woman who prepared an especially disgusting sauce, fukkho hoy, to express her discontent with her marginal social position within the household. Djebo was not simply a bad cook, or lacking in ability to taste; rather, in an act of "calculated distastefulness," she utilized her cooking as a tool for social critique. ${ }^{4}$ In the refugee camp, food aid was both disgusting and delicious, but the biopolitics of food aid positioned disgust and tastelessness as the unmarked norm, while delicious foods appeared as an impossible contradiction, matter out of place. To tease out the nature of social critique embedded in the culinary work invested in food aid, I focus on the sensual interplay of taste to show how refugees rejected the biopolitics of necessity.

In this article, I argue that Liberian refugees used taste as a tool to interpret and respond to the conditions of humanitarian aid in ways that challenge the logic of humanitarianism. David Sutton (2001, 89-90) has argued that smell and taste, as emotionally charged senses, "evoke what surrounds them in memory" but elude discursive formation: that is, humans react strongly to the sensory memories, but they struggle to articulate the dimensions of both smell and taste. Drawing from the treatment of the social life of things (Appadurai 1986), I trace biographies of taste to reflec how the classificatio and treatment of food provided to refugees 
produced a powerful, public accounting of the history and contemporary conditions of humanitarianism that challenges two foundational assumptions of humanitarian reason: first the inevitable inequality between the giver and receiver that prioritizes the humanitarian giver; and second, the unquestioned valuation of biological life above all else. Through the creation and categorization of refugee food, Liberians rejected the reason of humanitarian reason and repositioned the recipient as an essential figur in humanitarian aid.

I begin my argument by tracing a historical biography of taste from Liberia to Buduburam to set the stage for a critical inquiry into the politics of necessity. Following this discussion, I draw on my own sensory engagements at Buduburam to demonstrate the potential of taste to shift and critique the language and reason of humanitarianism. Focusing on the politics of necessity, my analysis of corn, an emblematic refugee food, reveals the ways in which refugees did not inherently acquire a taste for necessity, but relied on taste as a necessary tool for collectively navigating and responding to humanitarian aid. I then turn to the ways in which refugees privately struggled to maintain tasteful seasoning and exchange of food and suggest that the sensual experience of food aid destabilizes the authority and privilege of the humanitarian giver and repositions refugees as critical figure of humanitarian aid. Moving between the tastes and exchanges among refugees, I return to the public, collective form of refugee food to demonstrate how taste further disrupts the reason of humanitarian reason. Here I discuss two biographies of taste- drip and you-will-kill-me beans - that counter the preoccupation with biopolitics in contemporary humanitarian aid.

As previously mentioned, this article is based on ten months of research in the camp between 2005 and 2008-2009. In 2008-2009, I collaborated with a team of Liberian community health workers from the Children's Nutrition Center, a program run by the National Catholic Secretariat (a charitable arm of the Catholic Church in Ghana) and subcontracted by the United Nations High Commission for Refugees (UNHCR). Together, we conducted twenty-eight household food economy interviews with refugees, eleven interviews with key humanitarian aid stakeholders, three focus groups on social status, and two daily household food-economy logs for one month. We also administered 135 household foodeconomy surveys, including an ethnographic measure of household food-security status and social resource mapping (see Schiffer and Waale 2008). ${ }^{5}$ As a medium to contrast and bring my own phenomenological reading of Buduburam's food, I describe how my daily encounter with the smells, tastes, and sounds of the camp 
became a central component of my analysis, comprising a "sensory ethnography" (Pink 2009).

\section{SMELL-NO-TASTE}

On the way to Monrovia there is a town called Smell-No-Taste; it is a place where the intersection between humanitarianism and taste takes on a biopolitical life. The town acquired its moniker during World War II when the U.S. government built an airport in Liberia as a humanitarian gesture, though the project was brokered with the agreement that the United States would also maintain military use of the facility (Dunn 2009, 70). ${ }^{6}$ While it preceded formalized institutions of humanitarian aid, Smell-No-Taste foreshadows the ambiguities and violent potential of contemporary aid. With the launch of the new airport project, many Liberians moved near the site in search of temporary construction work. As some have explained to me, the labor migrants lived so close to the American military base that they could smell the cooking of American food, though they were never able to taste it. The smell of the American food passed into the nostrils of Liberians, but the American soldiers did not deign them worthy of a taste. According to testimony given to the Liberian Truth and Reconciliation Commission, the American soldiers instead abused Liberian civilians who ventured near the American base (Republic of Liberia Truth and Reconciliation Commission 2009, 120). ${ }^{7}$ While the Liberian laborers were eager to engage the American soldiers in hospitable relations, the soldiers appeared to disregard the Liberians as undeserving guests. In naming the town Smell-No-Taste, Liberians emphasized the dehumanization of this act and, at the same time, leveled a critique of the American soldiers' presence. Moreover, the town presents an enduring sensory record of the tasteless American inhospitality now codifie on a map and illustrates the historical legacy of humanitarian sentiment and intervention to perpetuate, rather than alleviate, suffering.

Located forty kilometers west of Accra along the busy international road stretching across the southern portion of Ghana rests a site of contemporary humanitarian intervention: the Buduburam Liberian refugee camp. It emerges from the landscape as a massive sprawl of concrete buildings and unpaved dirt pathways. A busy car park, police station, UNHCR trailers, a barbed-wire-protected camp manager's office and a market where Ghanaian and Liberian vendors peddled fresh, dried, fermented, and prepared foods, used clothing, and an array of household goods all marked the entrance to Buduburam. After the outbreak of civil war in Liberia in 1989, the Ghanaian government, with support from 


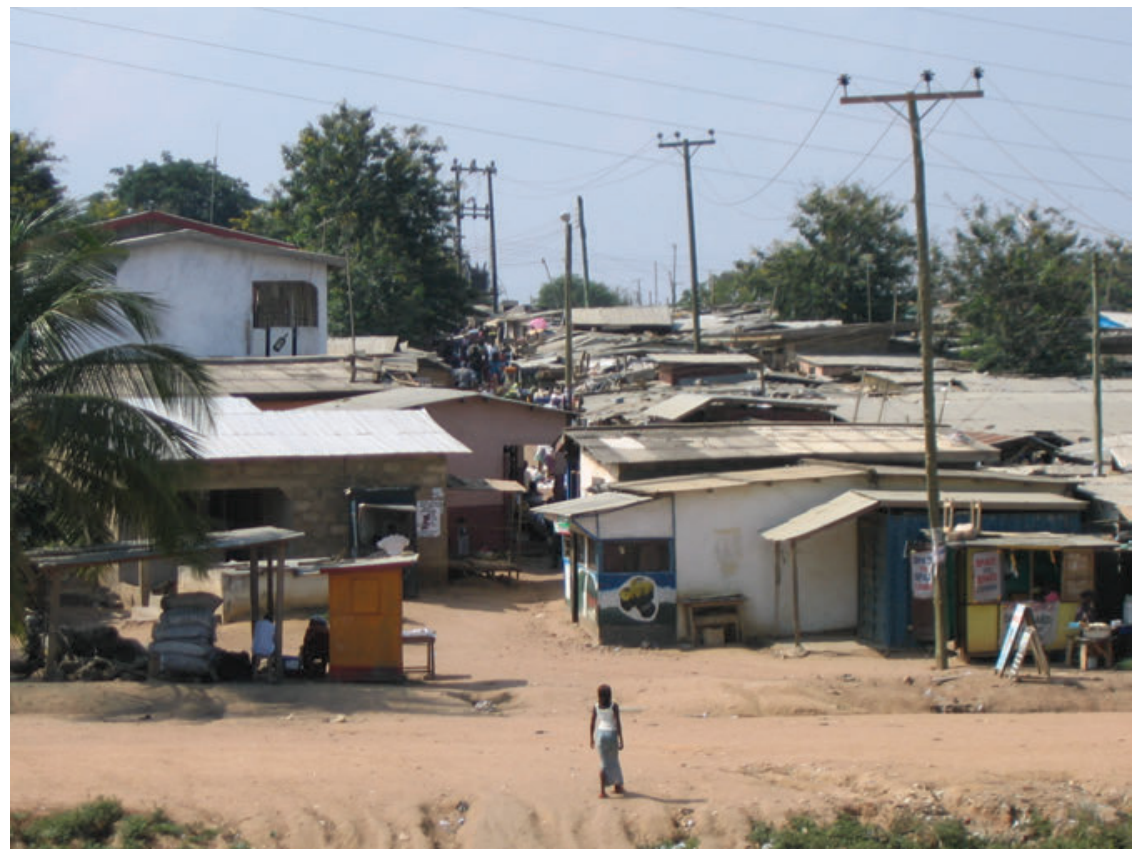

Figure 2. Side entrance to the Buduburam camp, with a path leading up through the market. Photo by Micah Trapp.

UNHCR, opened the Buduburam camp in August 1990 to accommodate the thousands of refugees who arrived in Ghana due to the hostilities. Over the course of more than two decades, the UNHCR and humanitarian aid organizations provided officia support in the form of refugee protection, food aid, health care, and educational programs. The World Food Program (WFP) initially provided wet (prepared) food aid at Buduburam, but this was soon replaced with dry (commodity) food rations, which consisted primarily of corn and soy products supplied by industrialized monocropping. Food aid followed a targeted assistance plan directed at refugees deemed "vulnerable," and by March 2009, fewer than six thousand refugees - of the projected twenty-four thousand officia refugees residing at Buduburam - were eligible to receive rations, despite widespread, chronic poverty. Each eligible individual was allowed to acquire the prescribed monthly rations: maize $(12.6 \mathrm{~kg})$, beans $(1.5 \mathrm{~kg})$, a corn-soya blend $(1.5 \mathrm{~kg})$, vegetable oil $(0.9 \mathrm{~kg})$, and salt $(0.15 \mathrm{~kg})$ (UNHCR 2009, 196). ${ }^{8}$ The standardized WFP rations were calculated based on minimum daily caloric requirements; in focusing on calories, humanitarian projects take the refugee camp as a site of culinary absence, minimizing the importance of taste in food aid. Nonetheless, 
for refugees to survive, the raw food rations need to be transformed into edible forms. In other words, refugees must cook.

Liberians possess a rich history of culinary innovation. The segment of the West African coast that now constitutes the Liberian nation used to be called the Grain Coast, given its prolifi production of rice. In Black Rice, Judith Carney (2001) countered more than a century of scientifi racism that attributed the ingenuity of rice production in the American South to plantation owners. In fact, it was those who crossed the Middle Passage that possessed the knowledge and skill of cultivating rice. ${ }^{9}$ In the Caribbean, Sidney Mintz $(1996,37)$ argued that the cooking practices and preferences of slaves expressed human potential, creating the foundation for freedom. However, as the colonization and founding of Liberia attests, cooking practices and tastes more frequently facilitate exploitation and exclusion. In the early nineteenth century, before the end of the transatlantic slave trade, the American Colonization Society (ACS) launched a colonization plan that eventually resulted in the founding of the Liberian nation in 1847. Members of the ACS felt threated by the presence of freed blacks from the Americas and justifie their plan as a benevolent process of returning home (Burrowes 2001). However, many of the black settlers - primarily middle-class, free black men and women who had experienced pervasive racism in the United States - did not identify with the indigenous population on the West African coast. Instead, they formed an elite group of Americo-Liberians and perpetuated their authority through embodied practices of distinction (Moran 1990, 58). Daily rituals of cleanliness, wearing Western dress, speaking English, eating with a fork, and baking bread in an oven became markers of being “civilized” (Fraenkel 1964, 270). ${ }^{10}$

Limited written accounts of food in Liberia have resulted in the glossing of diverse cuisines as "African food" or "West African food," but the variety of regional cooking practices and tastes in Liberia, alongside the incorporation of processed foods such as spaghetti, oats, canned goods, and certain vegetablescabbage, carrots, green beans, lettuce, and potatoes - and baked goods (e.g., shortbread; cornbread) from the American South as "civilized" foods points to a distinct cuisine reflectiv of centuries of migration. ${ }^{11}$ Like many cuisines, Liberian food is premised on a core staple consumed in tandem with a wide range of fringe foods, such as a sauce, soup, or stew prepared on a daily basis (Mintz 1986). ${ }^{12}$ Rice has endured as the preferred staple and life source for Liberians: most will say they have not eaten unless they have consumed rice. Cassava also contributes significantl to the caloric and nutritional base of the diet, but Liberians also boil, 


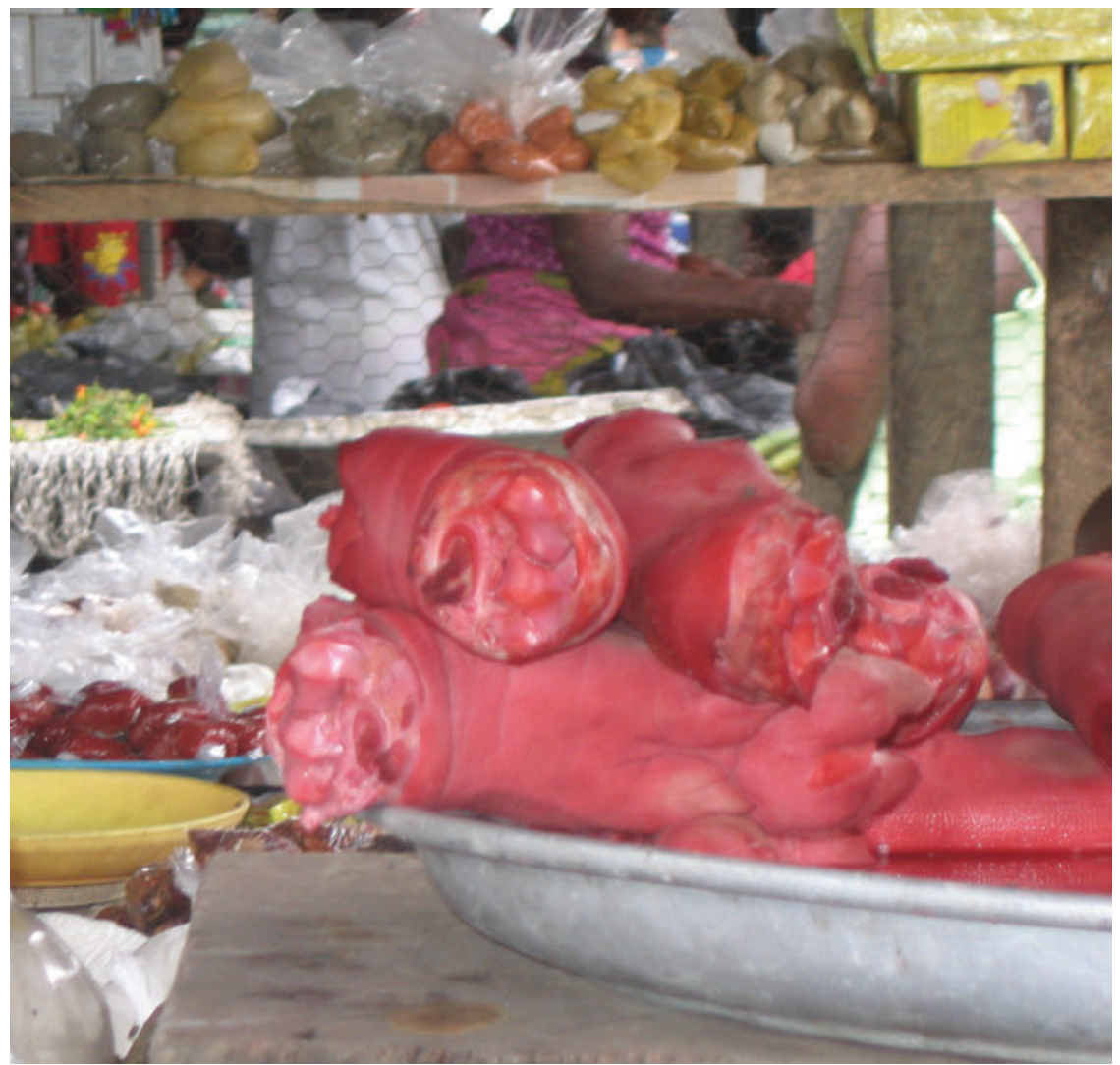

Figure 3. Pig feet at the market. Photo by Micah Trapp.

roast, and fry other starch crops, such as plantains, eddoes, yams, and corn. ${ }^{13}$ While starches are the foundation of a meal, a variety of sauces, including palm butter, groundnut stew, potato greens, palava sauce (made with jute or okra leaves), cassava leaves, pepper soup, beans, okra, garden egg (eggplant), and pumpkin (butternut squash) are made spicy through the liberal use of scotch bonnet peppers, and they are made rich through the addition of vegetable or red palm oil and multiple protein sources, including dried and fresh fish chicken, turkey, pig's feet, cow meat, crabs, shrimp, river snails, land snails, bush meat (such as dried monkey or wild boar), and spring chickens (frogs). Stews often exemplify regional food preferences: torborgee — a spicy stew prepared with bitterballs (pea eggplant), baking soda, and fermented red palm oil — is especially favored in the northwestern region of Lofa, while palm butter remains a specialty of the southeastern county of Maryland. ${ }^{14}$ With the founding of Liberia, regional 
variations in cooking were roughly cobbled together with cooking traditions from the American South to create a Liberian cuisine, a paradigm against which the new foods, tastes, and cooking practices of humanitarian aid were evaluated when Liberians were forced to occupy refugee camps following the war.

\section{THE ART OF EATING}

In 2005, my firs and only experience with eating WFP food rations in Buduburam introduced a new line of inquiry into my study of food aid: the simple act of eating demanded a critical engagement with the practice and reason of humanitarianism. At the time of my tasting, I lived with Mary, a Liberian woman who was an exceptional cook. One night, the heavy sound of the rainy season on the tin roof woke Mary and me to discover the rumbling of our bellies. We heard the tiny feet of mice scurrying about the small indoor cooking area as Mary lit a candle and searched for some of the leftover ground corn-soya blend (CSB) rations that her neighbor had given her earlier in the day. Though many Liberians regarded CSB as tasteless, we sat on the floor spooning into our mouths the hot porridge that Mary had made creamy and delicious through the addition of sugar and milk powder so that we could again fall asleep. If I had not been so hungry, I would not have joined my Liberian host in eating what I felt were precious rations, unintended for my consumption. However, this unexpected feast allowed me to taste the delicious potential of humanitarian aid transformed by a skilled cook. When I returned to Buduburam in 2008, I encountered CSB again as I chatted with Elizabeth, an elder at the camp. She spooned CSB - which she drytoasted over the fir until it had taken on a deep, amber color-out of a small glass jar. The CSB smelled pleasantly nutty, and I was intrigued by the new flavo

profil that Elizabeth had achieved without the addition of the fatty, expensive ingredients that Mary had used years earlier. Elizabeth's innovation was in fact indicative of the contractions and ambiguities of the changing scope of aid: the UNHCR was eager to close the camp, and humanitarian aid had all but crawled to a halt, leaving refugees to manage in an even scarcer terrain. ${ }^{15}$

The move to reduce humanitarian aid was politically motivated to encourage repatriation to Liberia, but Liberians placed a great social importance on sharing food and resisted the taste of necessity as they called out "let's eat!" to those who arrived or passed by when food was being consumed. Their exhortation "let's eat" demonstrates the openness and generosity of Liberians to both friends and strangers, and although living conditions were difficul at Buduburam, one man proclaimed that Liberians always knew that they would be able to get food because 
everyone shared. While hospitality played a significan role in Liberian society, this characterization of food sharing was idealistic: my household food-economy survey data revealed that 7 out of 135 surveyed households ( 5 percent) had taken to the troublesome and stigmatized act of regularly begging for food, while another 78 households (58 percent) had begged for food at least once while living at Buduburam. Liberian hospitality suffered in the refugee camp, and the invitation to eat took on additional meaning as Liberians managed a landscape of scare resources and hosts were frequently overextended. Circumstances such as these amplifie the dissonance between the tastes of necessity and those of luxury as refugees balanced their capacities and roles as both guest and host, a matter further magnifie by my presence (Serres 2007).

My appetite and taste for Liberian food was not without complications: I hailed from "America," the wealthy, privileged colonizer and sometimes benevolent benefactor, and I had an appetite in a refugee camp, where access to and distribution of food were measured, controversial, and laden with social meaning and inequality. In this environment I had to balance whether or not to accept food (this proved especially challenging when visiting a household with very limited means), how much I should eat (or could, if I was hungry, which I often was), where I ate, and whether I would contribute food to a household. When offered food, I usually ate a bite or two unless doing so would overextend the capacity of the host, but at Mary's house I felt freer to eat, given her access to resources and the depth of our social relationship, which allowed me to offer both food and money as a treat rather than as aid. Mary set aside food for me, and though she was an incredible cook, I rarely finishe it, because doing so would imply I was not satisfied However, one evening I was so hungry and the dry rice that she had prepared with okra, kittaly (dried bitterball), peppers, canned luncheon meat, and red palm oil was so delicious that I could not stop eating. Mary commented with surprise and slight irritation at my unexpected hunger. She revealed to me then that she relied on my observance of the social norm of leaving food, so that she could have a snack before sleeping. In this moment my hunger became both a nuisance and a methodological tool. Mary eventually allowed me to cook alongside her, often outside. Neighbors were amused by my interest in the arduous task of cleaning kiss meat, while others were concerned I would take this culinary knowledge back to America and make a profitabl business out of it, leaving Liberians with nothing. Though initially befuddled by this hostility, I came to understand my interest in cooking as a contemporary iteration of deeper histories of exploitation. Decentering the authority, privilege, and power I em- 
body as a potential humanitarian giver presents an opportunity for hostility to become a matter of critique and sets the stage for understanding how cooking and taste became a means of countering humanitarian reason.

\section{INHOSPITABLE REFUGEE FOOD}

Liberians often used the term refugee food to describe what they were able to access, prepare, and eat at Buduburam, and they generally used the phrase to refer to foods that were primarily functional - the tastes of necessity responsible for fillin the stomach - and not Liberian food. Liberians ate corn prior to exile, but at Buduburam it became an emblematic refugee food as it took the form of banku - a fermented and mashed mixture of cassava and corn similar to Liberian cassava $f u f u$ - and replaced rice when resources were limited. ${ }^{16}$ One afternoon, on entering the house of a husband, wife, and fiv children, I immediately inhaled the powerful, sour scent of fermenting corn. Cecelia, the mother, explained that she had been soaking their ration of corn for the past few days, but had delayed in preparing it because they had managed to get a few cups of rice. The cornbased food rations were consistent with Ghanaian dietary preferences, but they clashed with Liberian tastes. The notable blending-a process of creolization incorporating known and unknown foods - of corn into the dough produced a rough texture that significantl changed the taste of the staple (Wilk 2006, 114). Corn, or banku, more specifically as an emblematic refugee food demonstrates the ways in which refugees did not inherently acquire a taste for necessity, but relied on taste as a means of collectively navigating and responding to humanitarian food aid.

Liberians differed in their preferences for banku; many ate it privately, primarily out of economic necessity, while for others, the public preparation of banku reflecte the complex and contested relationships between cooking, taste, and humanitarianism. When I firs met Gloria, a Liberian woman who had lived at Buduburam since 1990, she insisted that she was hungry and that I, as a foreigner, should be able to help her get food. Adhering to my informed consent procedures, I told Gloria that I was prohibited from influencin food rations, but my compliance with bureaucratic protocol was taken as ridiculous: I certainly had the private resources to offer food and, therefore, should. Gloria's request nagged me, and so on Christmas morning, I went to the market and purchased the ingredients for the "rich" (delicious) palm butter she had described during our interview. When I arrived at her house, Gloria was astonished and, with a laugh, said that she did not actually expect me to bring food. Her request had been a 
statement about the conditions of scarcity at the camp, which she wanted me to document in my research records. Gloria positioned herself as an active participant in constructing my ethnographic account, and even though she did not expect or even want me to bring her food, she continued to ask me for food, reifying the humanitarian reason of the deprived moral subject. Weeks later, Gloria extended an invitation to share a meal of banku and grilled fish since I had not tasted her Christmas palm butter. As I enjoyed the sour, gritty tang of the banku-with crispy grilled fish hot pepper sauce, and the surprising bite of raw onion-Gloria confide that we would need to hide the fact that she had prepared banku from her neighbor. Gloria had already offered food to several guests that day and her small pot of banku could not be stretched further. Though her neighbor was a skilled cook and loved to eat banku, she did not prepare it because it was not Liberian food. The blending of corn into cassava fufu could privately be tasty, but the public taste of corn transformed it into a refugee food. Gloria's neighbor was a respected elder, talented cook, and comparatively well-off: preparing banku would potentially give other Liberians further grounds to question her solidarity with the plight of refugees at Buduburam. By consuming a refugee food, Gloria's neighbor would unwillingly promote the assumption that refugees should adopt the taste for necessity.

It was these sorts of public demonstrations surrounding the taste of banku, and refugee food more generally, that pointed to the inhospitable condition of refugee life in Ghana, where food had the potential to nourish, but was not inherently nourishing. In this environment, cooking and taste were a necessity. Rosaline, a young mother of six, prepared her food outside her front door in a charcoal cookpot. She was a deft cook and could quickly pull a boiling pot from the fir with only her bare hand. We chatted one afternoon as she prepared banku, which she then offered to a group of male neighbors sitting nearby. They promptly declined her offer with a colorful response that evoked their sense of disgust with banku and the overall inhospitality of the Ghanaian refugee food system. The outright, public rejection of banku as a disgusting Ghanaian food compressed corn into a symbolic iteration of refugee food, removing the nuance and deliciousness of its preparation (Wilk 2006, 118). The tastelessness of banku prevented Rosaline from being an adequate host while the collective creation and negotiation of refugee food induced a consciousness of, rather than consensus with, the tastes of necessity and humanitarian reason. Through private and public constructions, exchanges, and refusals of refugee food, Liberians revealed and engaged the reason of humanitarian reason. Their taste laid the foundation for its critique. 


\section{SEASONING AID}

Liberians remained proud of their well-seasoned, complex cuisine and their generous attitudes toward providing delicious food for all guests; but at Buduburam, refugees struggled to maintain tasteful seasonings and exchanges of food within the parameters humanitarian necessity. Buduburam was host to many foreigners: volunteers working for fledglin aid organizations, researchers, and officiall dispatched aid workers. Collectively glossed as "white," foreigners were considered a necessary but indistinct part of the humanitarian aid system. Foreigners frequently dismissed Liberian food as unpalatable and unhealthy: it was too spicy, too salty, or too oily. In initial interviews with refugees, I inquired about nutritious foods, but research participants did not understand what I meant by nutritious. Nourishment, for Liberians, was more frequently evaluated in terms of "richness" and the sensory pleasures of taste. Betty, a woman who regularly struggled to feed her family, described it this way: "My heart can't satisfy. . . . I want those things [plantains] today, but no hand [no money]. So I will not get it. So it will make me hungry. It will make me to be full when I cook it. . . . Oh, it can make me fat! My stomach can get full . . . so I can get fat. But now, now I can't get the thing I like, that what make me dry [skinny] like this.” What was good for the body was synonymous with what tasted good: food was a sensuous encounter, not simply a matter of sustaining biological life. But in the refugee camp, nourishment favored the embedded caloric norms of humanitarian reason. Aware that Liberians regarded maize with a kernel of disgust, aid workers were often defensive about the limits of donor-based aid. A WFP program office explained the challenges of accommodating refugee tastes: "Even though we try to make sure that taste, the beneficiaries tastes and so on [are taken] into account, we can't afford to give the rice. You understand? . . . It's very, very difficul for an agency, for WFP, to do rice. . . . Rice is a very expensive commodity. And if we want to reach as many beneficiaries you know, as you would like, you cannot afford to do rice."

The program office continued to grapple with the cultural significanc of taste in her comparison between Liberians at Buduburam and Liberians at the Krisan refugee camp in the Volta region of Ghana.

Like in Krisan, the people don't have any other sources of getting food. They all have fish They love the maize. In Buduburam they don't like the maize much. . . . Because you see, people in Buduburam have tried to keep their Liberian-ness about them, even though they have been here for nine- 
teen years, and that's not a bad thing at all. . . . But I think that in terms of adapting to what's available in Ghana, they haven't been able to do it so well. Whereas the other caseloads have been more open to what Ghana has to offer.

While the office attempted to laud Liberians at Buduburam for maintaining their cultural preferences, her implicit questioning of Buduburam Liberians' inability to adapt to Ghanaian tastes speaks to the challenges of aesthetic intolerance (Bourdieu 1984, 56). The moral undertone of needing to adapt "to what Ghana has to offer" deflecte the limits of humanitarian aid onto the cultural landscape of Ghana and the palates of Liberians, which should adjust to the tastes available.

Focusing on sensual experiences and the seasoning of food challenges the prioritization of the obligations (and tastes) of the humanitarian giver and repositions refugees as essential figure of humanitarian aid. In response to this, a U.S.-based Christian aid organization operating at Buduburam attempted to accommodate the Liberian taste for rice by providing fortifie rice for malnourished children. One morning I worked alongside the cooks at a children's feeding school that received this special rice. The cooks were preparing garden eggs (eggplant) for lunch, and it was my responsibility to pound the cooked vegetables into a sauce. Once I had finished the cooks instructed me to open the rice sent from the United States. The packets were unusually small - just one pound - and contained pussava, a parboiled rice much favored by Liberians, but they were also fortifie with textured soy protein, mushrooms, dehydrated vegetable bits, vitamins, and a seasoning mix. While rice and bouillon seasoning were consistent with Liberian tastes, several of the children had become sick after eating the rice, so much so that the weight measurements of the children dropped for two months following the introduction of the rice.

While the offering of fortifie rice maintained a commitment to the obligations of the humanitarian giver, the necessity of seasoning food to make it palatable situates the recipient as an active consumer of humanitarian aid. Bouillon, also called "chicken soup" or simply “cube," was one of the most widespread seasonings in Liberia and at Buduburam. Bouillon came in many brands, shapes (cube, rectangle), and flavor (chicken, shrimp, crawfish pig) and was typically sold in quantities of one or three. Cooks combined multiple flavor of cube in one pot, simmering with crawfis while finishin with a crumble of chicken. The technique of submersion incorporates one ingredient into another, so that each is rendered ambiguous, unknowable (Wilk 2006, 115), and the cooks at the 
feeding school had desperately tried submerging the taste of "that ugly rice" through cube, but to no avail. The headmistress of the school had appealed to the program director to alternate the nutritional fortifie rice with the more popular butter rice, but her request was denied. The U.S. organization had strict requirements for the use of aid: do not distribute it dry, prepare it according to the instructions, each package feeds six students, and take weekly weight measurements. When I returned to the United States, I visited the aid organization to interview one of the international program directors, who understood that rice was the favored staple of Liberians and aimed to provide food that would be both nourishing and delicious. While the rice reflecte the refugees' tastes, the organization's attempt to control the preparation and consumption of the rice nonetheless relegated refugees to the tastes of necessity. However, when faced with the prospect of "running stomachs" (diarrhea), the cooks countered the logic of humanitarian reason by instructing me to carefully remove the dried vegetables and soy before dumping the rice into the boiling water.

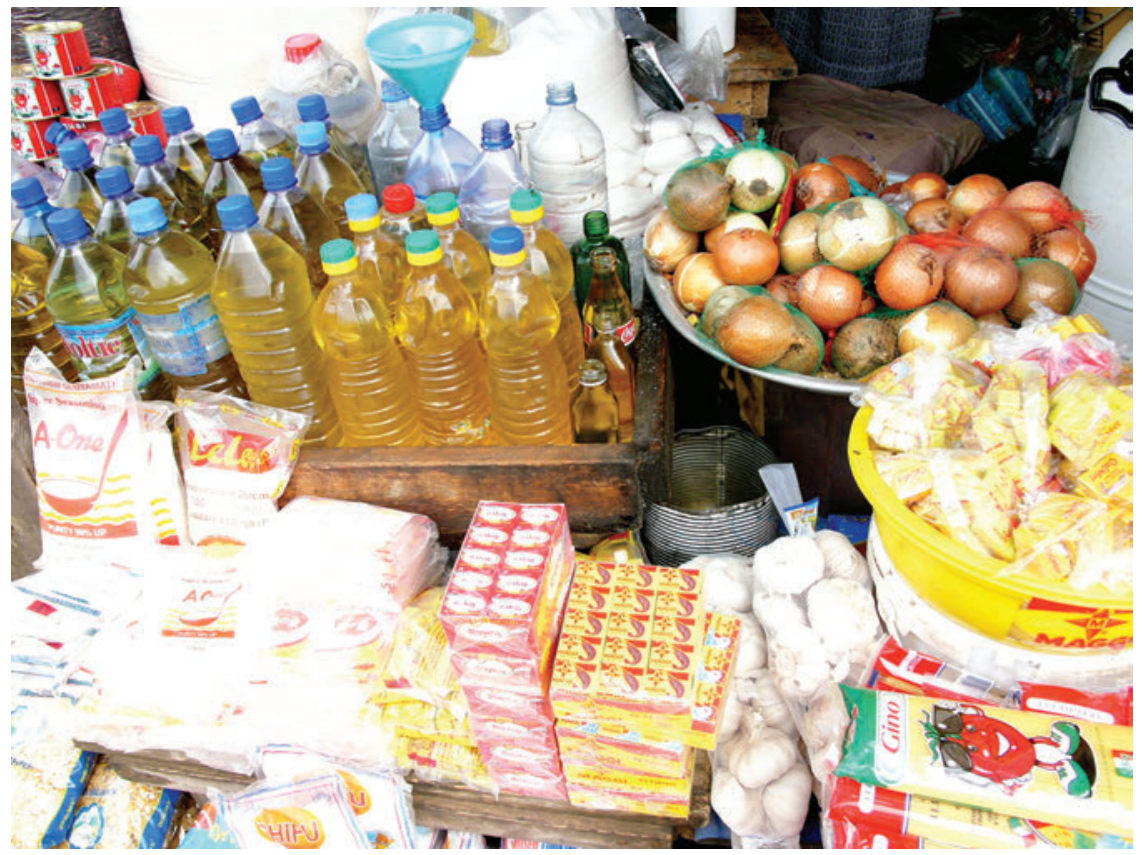

Figure 4. Varieties of cube and other seasonings for sale at a small market table.

Photo by Micah Trapp. 
The seasoning of food aid to make it both palatable and safe challenged the nutrient-based logic of humanitarian aid, but other contested acts of seasoning extended the critical capacity of taste to more directly impact refugee subjectivities and to dislodge the embedded prioritization of the humanitarian giver. On the afternoon that Gloria had invited me to eat banku, she had returned from the hospital where she had been under supervision for a heart problem. As her son prepared the banku, a young woman in the neighborhood came by the house to tell them to set aside food for her. After she left, Gloria and her son complained about the woman's frequent requests for food, but nonetheless set some aside. When they called the neighbor to eat, she tasted the food and immediately exclaimed in disgust that it needed cube. Gloria, her son, and their neighbor became quickly embroiled in a debate about the correct seasoning of the sauce. Gloria urged her son to put cube in the food, but he adamantly refused in silent defense of the doctor's orders that Gloria consume a low-sodium diet. The neighbor insisted the food did not taste good, and Gloria begged her son to add cube. At his continued refusal to do so, Gloria explained to her neighbor that white people did not eat salty food, with a notable glance in my direction. My presence only further angered the neighbor, who pointed out: "I'm not a white woman. I'm a black woman." Trying to calm her neighbor, Gloria urged her to get cube from inside the house, after which the woman stormed into Gloria's kitchen, took part of a cube, and crumbled it on top of her sauce. In this instance, the sensuous experience of taste revealed and challenged the whiteness and privilege of humanitarian aid; the insistence on cube repositioned the refugee — and the right of the guest to be satisfied - a a central and worthy subject.

\section{DANGEROUS AND DELICIOUS AID}

The taste of food aid acquired collective force as refugees embraced and constructed biographies of the sensuality of refugee food: two accounts - of drip and you-will-kill-me beans - challenged the embedded biopolitics of humanitarian reason. Liberians who needed to stretch their food money ate kokodolo, or kokoa Ghanaian corn porridge — in the morning and often at night to fil the stomach. ${ }^{17}$ One to two heaping spoons of sugar were poured into a plastic bag, followed by steaming hot, smooth liquid corn. The bag was tied tightly and one would simply bite off a corner of the bag and let the koko slide into the mouth. Although Liberians had consumed corn and oat porridge for breakfast prior to exile, at Buduburam they had taken to calling the porridge "drip," a renaming that highlighted its functional role as a mere "hunger killer" (Mintz 1986). The koko acted 
as an IV, allowing for the stomach to be fille with corn and sugar before sleep. Drip embodied a stylized form of presentation, serving, and eating: it was sold in a plastic bag that had to be raised above the head to allow the liquid to effortlessly slip down the throat. By acknowledging and embracing drip for its functional necessity, Liberians used the stylization characteristic of the tastes of liberty (Bourdieu 1984, 6) to produce the discursive innovation of drip. By bringing attention to its function as a hunger killer, drip highlights the conflatio of the refugee figur with the taste for necessity. The creative and facetious ingestion of drip as a life-support system challenged the medicalized approach of humanitarian aid. By dislodging humanitarian reason from the experience of being a refugee, refugees challenged the expectation to assimilate to the tastes of the humanitarian aid system. Liberians "interpret[ed] . . . the scarcity on offer and counter[ed] . . . it with an abundance not merely as compensation but as if to show the inanity of the very premise of scarcity it comports" (Abbas 2014, 518). ${ }^{18}$ In preparing, serving, and even relishing the abundance of corn, refugees revealed the inanity of a humanitarian aid system premised on the restrictive and inhumane expectation of the refugee as a tasteless subject.

Food aid at the Buduburam camp adhered to a supplementary food program; provisions added nutrients to an existing base of food. As one step beyond the bare caloric minimum, proteins occupied an ambiguous position in food aid and the informal classificator scheme of refugee foods. As protein sources, beans introduced through humanitarian aid were rendered both delicious and disgusting. As provisions of humanitarian aid, beans became a commentary on the taste for necessity and a critique of humanitarian reason. In a food-ration basket containing primarily starches, beans provided a vital source of protein, but they also confused the distinction between the tastes for necessity and luxury. Liberians prepared beans in a variety of ways - bean gravy, beans torborgee (a variation on the preparation of bitterballs [pea eggplants] with baking soda and fermented red palm oil) _ and the presence of beans in the refugee camp did not automatically signal a refugee food. The ambiguity of beans required more explicit classificator work for taste to operate as a critique of humanitarian reason.

Prior to exile in Ghana, Liberians were exposed to humanitarian tastes when the WFP introduced lentils in Liberia during the war. Lentils, as a legume, were fairly flexible and many Liberians incorporated them into their diet by preparing them in the same way that they prepared beans. According to Richard Wilk (2006, 116), the incorporation of new foods usually occurs alongside shortage or hardship. Although the transformation of food may include renaming the food to 
distinguish it from its previous form, in many cases, the substitution attempts to conceal the change. Yet when incorporating lentils into their diets, Liberians did not attempt to hide the substitution, but instead renamed lentils "you-will-killme beans." Liberians shared a number of explanations for this particular designation with me. In one account, you-will-kill-me beans arrived in Liberia during the war and tasted so "sweet" (delicious) and heavy that one would eat them, fall asleep, and be killed by rebels in one's heavy sleep. In another interpretation, a man cooked four cups of beans and four cups of rice, ate it all, and went to sleep. He never woke up. In a third narrative, you-will-kill-me beans were one of the firs foods provided by the United Nations to refugees. Because there was no other food available, Liberians ate the beans until they were full and would be killed by the monotony of eating the beans. In a fina account, a man was said to have been eating the beans every day because he did not have enough money for rice. The man said, "if these beans don't kill me, I will kill them."

The accounts of you-will-kill-me beans utilize the preparation and taste of the beans to tell a story about how Liberians understood and responded to the politics of necessity. In each case, the narrative confronts the prioritization of biopolitical life. In the firs narrative, the deliciousness of the beans distracts the humanitarian subject from the threat of war and points to the danger of blindly accepting and ingesting aid or expecting that it will alter the conditions that prompted the need for humanitarian aid in the firs place. It reproduces the status quo of armed love. But the narrative also critiques the prioritization of biological life embedded in humanitarian reason: tasting the sweet deliciousness of the beans becomes worthy of the sacrific of life. In the second narrative, the deprived humanitarian subject encounters the delicious and dangerous potential of the beans and consumes it with abandon: the abundance results in a gluttonous biological demise. The third narrative similarly highlights the monotony of food aid, but exclusively points to the disgust for and dangers of the beans. The explicit hailing of the UNHCR in this narrative holds the United Nations and humanitarian aid more generally accountable when the abundance and accompanying monotony of the taste of necessity becomes unbearable, producing a direct critique of the contradictions of humanitarian reason as both prioritizing and destroying life. The fina narrative also foregrounds the disgust and displeasure of the beans, but instead of succumbing to the violent potential of humanitarian aid, the man exclaims that he will kill the beans before they kill him. He rejects the taste for necessity embedded in humanitarian aid. These diverse etymologies of you-will-kill-me beans direct attention to the dual force of humanitarian aid as a life-sustaining, as 
well as life-threatening force. More significantly these narratives collectively produce biographies of taste to counter the reproduction of the biopolitical politics of necessity.

\section{CONCLUSION: Sensible Aid}

In his article "Alimentary Agents: Food, Cultural Theory, and Multiculturalism," Ben Highmore (2008) presents the chili pepper as an agent of alimentary pedagogy. The proclivity of British men toward the "aggressive consumption" of vindaloo in England presents a contested moment of multicultural exchange in which the food object resists domination: as the chili takes its forceful leave from the body, it teaches the colonizer a powerful lesson. "Aggressive consumption" and the alimentary journey of the spicy curry contrasts starkly with both the Liberian laborers who longed for a taste of the delicious food prepared by American soldiers and the Liberian refugees who were relegated to the monotonous consumption of bland food aid. But in each case, the sensuality of food expands our perception of social relationships and power. In the firs instance, Liberians were not able to taste the food and became the subjects of abuse, but in turn, they used their sensory experiences to mark their exclusion through the moniker of Smell-No-Taste. At Buduburam, the sustained alimentary encounters with food aid positioned refugees as humanitarian subjects, but the cooking and eating of refugee food also became a means for refugees - as guests and subjects of the politics of necessity - to engage and counter the logic of humanitarian reason.

In situating food as an alimentary agent and central figur in the creation and exchange of both knowledge and power, Highmore (2008, 393) draws on Jacques Rancière's notion of aesthetics as "the entire 'distribution of the sensible,"” where "sensible" does not simply refer to reason or common sense, but is a matter of perception, "what is perceived and perceivable." By tracing food aid through sensuous biographies of taste, I have argued that refugees do not inherently have, or acquire, a taste for necessity. Rather, taste is a necessity in humanitarian aid. Refugees blended, compressed, submerged, and substituted food rations into refugee food, producing a palatable and politicized cuisine. At Buduburam, the alimentary and aesthetic acts associated with refugee food defie the reason of humanitarian reason by expanding the perception of humanitarianism from the biopolitics of salvation to a more complex terrain of sensual subjectivities. Rather than swallow the taste of necessity, Liberians sensed and articulated biographies of food aid that recount and resist the violent potential of humanitarian reason. The act of tasting, sensing and articulating either good or bad flavor and effects, 
was not simply an account of a particular food, but rather a biopolitical statement about how refugee subjects understood their relative precarity. Taste constituted a way to overcome the abject reason of humanitarian interventions and to instead prioritize sensual subjectivity over rationalized biopolitics.

Tracing the biographies of taste in Buduburam shows us the articulation and legibility of refugee food for those who give to their neighbors but do not receive, or palatably taste, humanitarian aid. Encounters with rice, corn, and beans emerged in the discursive forms of ugly rice, drip, and you-will-kill-me beans to shift the fragments of individual tastes into a collective aesthetics that challenged two foundational assumptions of humanitarian reason. Seasoning and the alimentary experiences of ugly rice and a cube-less sauce positioned refugee guests as central subjects in humanitarian aid, where tastelessness surfaced as a lesson about the assumed depravity of humanitarian subjectivity. In the private exchanges and refusals of food among refugees, Liberians maintained the right to be satisfie and to resist the nutritional logic embedded in humanitarian aid. The sensuality of porridge transformed drip into a demonstrable refugee food and hunger killer. It expanded the perception of aid from one of biopolitics to an alimentary experience laden with geopolitical power. The diverse etymologies of you-will-kill-me beans became pedagogical agents that demonstrated the life-sustaining and life-threatening force of food aid, revealing moments in which the biopolitics of being a humanitarian subject were unbearable. Taken together, the collective biographies of taste performed through refugee food expand the distribution of the sensiblewhat is perceived and perceivable — within humanitarian aid, as well as the sensibility, the logic and the reason, of humanitarianism.

\begin{abstract}
Despite their nuanced palates and cooking skills, as guests at the humanitarian table, Liberians living at the Buduburam refugee camp in Ghana were expected and assumed to adapt to the "tastes of necessity." In the refugee camp, the sensory experiences and pleasures of the taste of liberty — or "luxury" - existed, if at all, as an indicator that one was no longer in need of aid. In this article, I consider how innovations in cooking and taste shape humanitarian politics and argue that Liberian refugees subverted the biopolitics of necessity through biographies of taste. Through their sensuous encounters and critical responses to the taste of necessity, humanitarian subjects are able to produce biographies of food aid and a public accounting of the historic and contemporary conditions of humanitarianism. By prioritizing the taste of refugee food, camp residents have challenged the reason of humanitarian reason by expanding the sensibility of food aid and repositioning recipients as essential figures
\end{abstract}


in humanitarian aid. [taste; humanitarianism; food aid; refugees; biopolitics; West Africa]

\section{NOTES}

Acknowledgments Thanks to Cymene Howe, the Cultural Anthropology editorial collective, and the anonymous reviewers for their generous comments and feedback. Numerous colleagues have also provided support and review at various stages in the development of this work. Dolores Koenig, David Vine, and Geoffrey Burkhart provided valuable input on the early stages of this project. Katherine Lambert-Pennington, Jennifer Simpson, and Erin Trapp have read and encouraged numerous drafts of this work. I am also grateful to discussions with fellow panelists at the 2012 American Anthropological Association meetings, where I presented the seeds of this work. My Liberian collaborators at the Buduburam camp were tireless in their efforts to help me unravel the meaning and impact of food aid. This work would not have been possible without the generosity and candor of those who opened their homes to me at the Buduburam camp; I am deeply grateful for many meals and conversations. This research was funded by a Doctoral Dissertation Improvement Grant (Award no. BCS-050719) from the National Science Foundation. I take sole responsibility for any misrepresentations, errors, or omissions.

1. In this article, I use humanitarianism to refer to a moral ethos that manifests outside formal institutions of aid, while humanitarian aid refers to the formalized institutions of aid.

2. See Malkki 1995, 216-17, on the "problem" of rich refugees.

3. In the Democratic Republic of Congo, Nancy Rose Hunt (2010) attended to acoustic memories - the sounds of laughing and crying women - to confront the dominance of the humanitarian apparatus and to articulate the possibilities for repetition and difference in the production of humanitarian subjectivities over time.

4. In contrast to culinary art, where "whether or not a cook is successful, a cook trie[s] to serve only foods of superior flavo to a guest, that is, foods prepared with the highest technical skill possible" (Adapon 2008, 47).

5. I used social resource maps to collect data on an individual's social relations and resource exchanges in the form of money, food, provisions, labor, and emotional/spiritual support. Participants used a bean allocation method to evaluate the weight or significanc of each relationship.

6. This is a historic example of the characterization advanced by Didier Fassin and Marielle Pandolf $(2010,12)$ that sees contemporary humanitarianism as "the politics of military intervention ... now played out in the name of humanitarian morality."

7. Eyewitness testimony presented in the fina report of the Republic of Liberia Truth and Reconciliation Commission $(2009,91)$ suggests that American soldiers stationed near Smell-No-Taste went beyond abuse and even killed Liberian civilians, but this testimony has not been investigated or confirmed

8. Vulnerability was define as: individuals sixty years and older, including their dependents; malnourished children and their immediate family members; individuals with disabilities; individuals with chronic or terminal illnesses (HIV, TB, cancer) and their dependents; unaccompanied minors; and socially vulnerable individuals.

9. Plantation owners sought slaves from specifi ethnic groups because they possessed knowledge and techniques of rice cultivation (Carney 2001, 80).

10. Education (Moran 1990) and salary (Tonkin 1981) were prominent "civilized" characteristics.

11. Existing accounts of Liberian cooking include Liberian Cookhouse Cooking (Keenan 1997), produced by the Friends of Liberia (mostly former Peace Corps workers), and Kwi Cooking (D'Azevedo 1962), created by the wife of the anthropologist Warren d'Azevedo. Kwi is a Kru word that refers to "civilized" or "Westernized." 
12. At Buduburam, many households were unable to cook daily and relied on an oftenunrefrigerated pot of soup for two or three days.

13. Cassava is prepared in a variety of ways, as fufu (dried and fermented cassava, boiled and beaten), GB (peeled and boiled cassava, beaten into a dense substance), dumboy (peeled and boiled cassava, beaten less than GB to provide a softer texture), gari (dried cassava, pounded to small flakes prepared with hot water or eaten dry), and deepa (dried cassava, pounded to dust and cooked with hot water).

14. Maryland County was initially settled by the Maryland Colonization Society.

15. After nearly two decades of existence, Buduburam had acquired the bureaucratic label of a "protracted refugee situation," which reflecte a shift away from humanitarian interest to support for the repatriation of refugees to Liberia.

16. Judith Carney $(2001,73)$ has argued that on the Upper Guinea coast, maize "became indelibly associated with slavery in Africa." This may have contributed to the negative reception of corn among Liberians.

17. Kokodolo was sold at street stalls by Ghanaian vendors and was not necessarily made with food rations.

18. I thank Erin Trapp for pointing me to this interpretation of abundance and scarcity.

\section{REFERENCES}

Abbas, Asma

2014 "In Terror, In Love, Out of Time." In At the Limits of Justice: Women of Colour on Terror, edited by Suvendrini Perera and Sherene H. Razack, 503-25. Toronto: University of Toronto Press.

Adapon, Joy

2008 Culinary Art and Anthropology. New York: Berg.

Agier, Michel

2010 "Humanity as an Identity and Its Political Effects (A Note on Camps and Humanitarian Government)." Humanity: An International Journal of Human Rights, Humanitarianism, and Development 1, no. 1: 29-45. http://dx.doi.org/10.1353/ hum.2010.0005.

Annear, Christopher M.

2004 "'GM or Death': Food and Choice in Zambia." Gastronomica 4, no. 2: 16-23. http://www.gastronomica.org/gm-death-food-choice-zambia/.

Appadurai, Arjun

1986 "Introduction: Commodities and the Politics of Value." The Social Life of Things: Commodities in Cultural Perspective, edited by Arjun Appadurai, 3-63. New York: Cambridge University Press.

Bourdieu, Pierre

1984 Distinction: A Social Critique of the Judgment of Taste. Translated by Richard Nice. Cambridge, Mass.: Harvard University Press.

Burrowes, Carl Patrick

2001 "Black Christian Republicanism: A Southern Ideology in Early Liberia, 1822 to 1847.” Journal of Negro History 86, no. 1: 30-44. http://dx.doi.org/10.2307/ 1350177.

Carney, Judith

2001 Black Rice: The African Origins of Rice Cultivation in the Americas. Cambridge, Mass.: Harvard University Press.

D’Azevedo, Kathy

1962 "Kwi Cooking." Self-published pamphlet in the author's possession.

Dunn, Elizabeth

2011 "The Food of Sorrow: Humanitarian Aid to Displaced People." In Food: Ethnographic Encounters, edited by Leo Coleman, 139-49. New York: Bloomsbury. 
Dunn, Elwood D.

2009 Liberia and the United States during the Cold War: Limits of Reciprocity. New York: Palgrave Macmillan.

Fassin, Didier

2012 Humanitarian Reason: A Moral History of the Present. Berkeley: University of California Press.

Fassin, Didier, and Mariella Pandolf

2010 "Introduction: Military and Humanitarian Government in the Age of Intervention." In Contemporary States of Emergency: The Politics of Military and Humanitarian Interventions, edited by Didier Fassin and Mariella Pandolfi 9-25. New York: Zone Books.

Fassin, Didier, and Richard Rechtman

2009 The Empire of Trauma: An Inquiry into the Condition of Victimhood. Translated by Rachel Gomme. Princeton, N.J.: Princeton University Press.

Feldman, Ilana

2012 "The Humanitarian Condition: Palestinian Refugees and the Politics of Living." Humanity: An International Journal of Human Rights, Humanitarianism, and

Fraenkel, Merran Development 3, no. 2: 155-72. http://dx.doi.org/10.1353/hum.2012.0017.

1964 Tribe and Class in Monrovia. London: Oxford University Press.

Freidberg, Susanne

2003 "French Beans for the Masses: A Modern Historical Geography of Food in Burkina Faso.” Journal of Historical Geography 29, no. 3: 445-63. http:// dx.doi.org/10.1006/jhge.2002.0487.

Highmore, Ben

2008 "Alimentary Agents: Food, Cultural Theory, and Multiculturalism." Journal of Intercultural Studies 29, no. 4: 381-98. http://dx.doi.org/10.1080/ 07256860802372337.

Hunt, Nancy Rose

2010 "An Acoustic Register, Tenacious Images, and Congolese Scenes of Rape and Repetition." Cultural Anthropology 23, no. 2: 220-53. http://dx.doi.org/ 10.1111/j.1548-1360.2008.00008.x.

Keenan, Joan

1997 Liberian Cookhouse Cooking. Washington, DC: Friends of Liberia.

Knudsen, John Chr.

1995 "When Trust is on Trial: Negotiating Refugee Narratives." In Mistrusting Refugees, edited by E. Daniel Valentine and John Chr. Knudsen, 13-35. Berkeley: University of California Press.

Macbeth, Helen, ed.

1997 Food Preferences and Taste: Continuity and Change. New York: Berghahn.

Malkki, Liisa $\mathrm{H}$.

1995 Purity and Exile: Violence, Memory, and National Cosmology among Hutu Refugees in Tanzania. Chicago: University of Chicago Press.

1996 "Speechless Emissaries: Refugees, Humanitarianism and Dehistoricization." Cultural Anthropology 11, no. 3: 377-404. http://dx.doi.org/10.1525/can. 1996.11.3.02a00050.

McKay, Ramah

2012 "Afterlives: Humanitarian Histories and Critical Subjects in Mozambique." Cultural Anthropology 27, no. 2: 286-309. http://dx.doi.org/10.1111/j.15481360.2012.01144.x.

Mintz, Sidney W.

1986 Sweetness and Power: The Place of Sugar in Modern History. New York: Penguin.

1996 Tasting Food, Tasting Freedom: Excursions into Eating, Culture, and the Past. Boston: Beacon Press. 
Moran, Mary H.

1990 Civilized Women: Gender and Prestige in Southeastern Liberia. Ithaca, N.Y.: Cornell University Press.

Pink, Sarah

2009 Doing Sensory Ethnography. Thousand Oaks, Calif.: Sage.

Redfield Peter, and Erica Bornstein

2010 "An Introduction to the Anthropology of Humanitarianism." In Forces of Compassion: Humanitarianism Between Ethics and Politics, edited by Erica Bornstein and Peter Redfield 3-30. Santa Fe, N.M.: School for Advanced Research Press.

Republic of Liberia Truth and Reconciliation Commission

2009 "Volume II: Consolidated Final Report." June 30. http://trcofliberia.org reports/final-repor .

Schiffer, Eva, and Douglas Waale

2008 "Tracing Power and Influenc in Networks: Net-Map as a Tool for Research and Strategic Network Planning.” Discussion Paper 00772. Washington, DC: International Food Policy Research Institute. http://www.ifpri.org/

Serres, Michel publication/tracing-power-and-influence-network .

2007 The Parasite. Translated by Lawrence R. Schehr. Minneapolis: University of Minnesota Press.

Stoller, Paul

1989 The Taste of Ethnographic Things: The Senses in Anthropology. Philadelphia: University of Pennsylvania Press.

Sutton, David E.

2001 Remembrance of Repasts: An Anthropology of Food and Memory. New York: Berg.

Ticktin, Miriam

2011 Casualties of Care: Immigration and the Politics of Humanitarianism in France. Berkeley: University of California Press.

2014 “Transnational Humanitarianism.” Annual Reviews of Anthropology 43: 273-89. http: / /dx.doi.org/10.1146/annurev-anthro-102313-030403.

Tonkin, Elisabeth

1981 “Model and Ideology: Dimensions of Being Civilised in Liberia." In The Structure of Folk Models, edited by Ladislav Holy and Milan Stuchlick, 305-30. New York: Academic Press.

United Nations High Commission for Refugees (UNHCR)

2009 “Ghana.” In UNHCR Global Appeal 2009 Update, 196-99. http://www.unhcr. org/4922d41a0.html.

United Nations High Commission for Refugees and World Food Programme

2007 "Joint Self-Reliance and Food Security Assessment. Ghana: Volta Region, Buduburam, and Krisan.” Report, January. http://www.wfp.org/content/ Wilk, Richard ghana-unhcrwfp-joint-self-reliance-and-food-security-assessment-january-2007.

2006 Home Cooking in the Global Village: Caribbean Food from Buccaneers to Ecotourists. New York: Berg. 